\title{
Peran Media Pembelajaran Guru Pendidikan Anak Usia Dini (PAUD) di Provinsi Jambi
}

\author{
Mahyudin \\ Universitas Terbuka \\ Correspondence email: mahyudin@ecampus.ut.ac.id
}

\begin{abstract}
Abstrak. Media sangat berperan dan memiliki fungsi strategis yang secara langsung maupun tak langsung dapat memengaruhi motivasi, minat dan perhatian bagi anak usia dini dalam dalam belajar. Tujuan penelitian ini untuk mengetahui peran media pembelajaran Guru PAUD di Provinsi Jambi. Metode yang digunakan adalah deskriptif kuantitatif dengan teknik cluster sampling, dalam hal ini adalah Kabupaten dan Kota di Provinsi Jambi sebagai klusternya. Jumlah satuan pendidikan (sekolah) anak usia dini di antaranya TK/RA, KB, TPA, dan SPS sebannyak 7.584. Kemudian setiap Kabupaten dan Kota dipilih sebanyak $10 \%$ secara random guru PAUD dari masing-masing sekolah. Sehingga jumlah sampelnya 758. Instrument penelitian berupa angket atau kuesioner Media Perception Evaluation Scale (MPES) yang berisikan 28 item pertanyaan. Data untuk semua parameter menggunakan database Microsoft Excel. Korelasi pearson digunakan untuk mempelajari korelasi antara variabel dan uji-t independen digunakan untuk membandingkan kelompok dengan SPSS versi 22. Semua analisis statistik dilakukan pada tingkat signifikansi $5 \%$ dan $\mathrm{P}<0,05$ dianggap signifikan secara statistik. Hasil penelitian bahwa media pembelajaran sangat berperan dalam proses pembelajaran untuk anak-anak PAUD di Provinsi Jambi. Hasilnya sebanyak 59,6\% menjawab sangat setuju. Melaluihasil analis SPSS dimana pernyataan media visual yang paling berpengaruh dalam pembelajaran guru PAUD di provinsi Jambi yaitu pernyataan 18,19,20,21, dan 22 dimana 100\% yang menyatakan bahwa media visual dapat memberikan motivasi, sedangkan pernyataa yang tidak berpengaruh yaitu pernyataan 17 dimana hanya 50,4\% yang menyatakan bahwa media visual dapat memberikan motivasi. Hal ini dapat disimpulkan bahwa penggunaan media pembelajaran pada anak usia dini sangat berperan untuk memotivasi, merangsang, bereksplorasi dan bereksperimen.
\end{abstract}

Kata Kunci: media pembelajaran; guru; PAUD

\begin{abstract}
The media is very instrumental and has a strategic function that directly or indirectly can affect motivation, interest and attention for young children in learning. The purpose of this study was to determine the role of PAUD teacher learning media in Jambi Province. The method used is descriptive quantitative cluster sampling technique, in this case the District and City in Jambi Province as the cluster. The number of early childhood education units (schools) include TK / RA, KB, TPA, and SPS, totaling 7,584. Then every District and City was selected by $10 \%$ randomly PAUD teachers from each school. So the number of samples was 758. The research instrument was a questionnaire or Media Perception Evaluation Scale (MPES) questionnaire containing 28 question items. Data for all parameters using a Microsoft Excel database. Pearson correlation was used to study the correlation between variables and independent t-test was used to compare groups with SPSS version 22. All statistical analyzes were carried out at a significance level of $5 \%$ and $P<0.05$ was considered statistically significant. The results of the study show that learning media plays an important role in the learning process for PAUD children in Jambi Province. As a result $59.6 \%$ answered strongly agree. Through the SPSS analyst results where the most influential visual media statements in PAUD teacher learning in Jambi province are statements 18,19,20,21 and 22 where $100 \%$ stated that visual media can provide motivation, whereas statements that had no effect were statements 17 where only $50.4 \%$ stated that visual media can provide motivation. It can be concluded that the use of learning media in early childhood is very instrumental to motivate, stimulate, explore and experiment.
\end{abstract}

Keywords: learning media; teacher; PAUD

\section{PENDAHULUAN}

Kita sadari bahwa pembelajaran merupakan suatu sistem, terdapat di dalamnya sejumlah komponen yang saling berhubungan satu sama lain untuk mencapai tujuan. Komponen tersebut berupa: (1) tujuan, (2) bahan/materi ajar, (3) metoda, (4) alat/media dan, (5) evaluasi. Pembelajaran merupakan suatu sistem untuk itu, keberhasilan dalam pembelajaran sangat ditentukan oleh sejauh mana efektivitas tiap-tiap komponen tersebut berinteraksi. Salah satu komponen pembelajaran adalah media. Dimana proses belajar dan mengajar merupakan proses komunikasi antara pebelajar (guru) dan pembelajar (peserta didik). Komunikasi yang dilakukan guru kepada peserta didik yaitu secara non-verbal yang memerlukan media. Hal ini berarti media mutlak harus ada dan dimanfaatkan didalam proses pembelajaran.

Menurut Asyhar (2012) menyatakan bahwa media merupakan komponen yang sangat penting, yaitu suatu sarana atau perangkat komunikasi antara komunikator dan komunikan. Pada dasarnya belajar yaitu melakukan aktivitas, maka dalam proses pembelajaran perlu banyak partisispasi dari para peserta didik. Partisipasi dari para peserta didik dapat dilakukan dengan jalan mendengarkan, melihat, membaca, menulis, merasakan, dan memikirkan. 
Pentingnya peran media pembelajaran terhadap proses pembelajaran peserta didik. Selain itu, media berperan dan fungsi strategis yang secara langsung maupun tak langsung dapat memengaruhi motivasi, minat dan perhatian peserta didik dalam dalam belajar serta mampu memvisualisasikan materi yang abstrak yang dibelajarakan sehingga memudahkan pemahaman peserta didik. Media mampu membuat pembelajaran lebih menarik (Joyfull learning), pesan dan informasi menjadi lebih jelas memanipulasi dan menghadirkan objek yang sulit dijangkau oleh peserta didik (Asyhar, 2012).

Sementara itu, menurut Zaman dan Eliyawati (2010) menyatakan peranmediadalam proses pembelajaran khususnya untuk pendidikan anak usia dini (PAUD) semakin penting. Karena, mengingat perkembangan anak pada saat itu berada pada masa berfikir konkret. Hal ini merupakan salah satu prinsip pendidikan untuk anak usia dini harus berdasarkan realita. Yang berarti anak diharapkan dapat mempelajari sesuatu secaranyata. Dengan demikian dalam pendidikan untuk anak usia dini harus menggunakan sesuatu yang memungkinkan anak dapat belajar secara konkret. Prinsip tersebut mengisyaratkan perlunya digunakan media sebagai saluran penyampai pesan-pesan pendidikan untuk anak usia dini. Seorang guru pada saat menyajikan informasi kepada anak usia dini harus menggunakan media agar informasi tersebut dapat diterima atau diserap anak dengan baik dan pada akhirnya diharapkan terjadi perubahan-perubahan perilaku berupa kemampuan-kemampuan dalam hal pengetahuan, sikap, dan keterampilannya.

Untuk mengembangkan aspek kemampuan tersebut diperlukan media pembelajaran yang beragam dan bervariasi agar stimulasi yang diberikan kepada anak membuahkan hasil yang maksimal. Ada beberapa media pembelajaran yang khusus didesain oleh guru untuk mengembangkan atau menstimulasi kemampuan anak. Sehingga mudah bagi guru untuk mencarinya. Selain itu, terdapat perbedaan karakteristik pada setiap anak usia dini. Misalnya, karakteristik utama anak usia dini adalah anak bersifat egosentris yang memiliki cara pandangnya sendiri. Disini guru/pendidik ingin mengukur sikap anak terhadap kemampuan kerjasama kelompok, maka digunakan media permainan dimainkan secara berkelompok seperti permainan sepak bola atau permainan menyusun balok.

Menurut data dari Kemendikbud (2018) di Provinsi Jambi terdapat 7.584 Pendidik AUD yang di dalamnya dari satuan pendidikan (sekolah) anak usia dini diantaranya TK/RA, KB, TPA, dan SPS. Dari data tersebut dapat kita lihat penjelasan diatas tentang betapa penitingnya peranan media pembelajaran terhadap perkembangan peserta didik. Terutama pada peserta didik anak usia dini.

Pentingnya media pembelajaran dalam proses pembelajaran pada pendidikan anak usia dini ini membuat peneliti tertarik untuk meneliti peran media pembelajaran yang digunakan oleh Guru PAUD yang berada di Provinsi dengan mengangkat judul penelitian yaitu: "Peran Media Pembelajaran Guru Pendidikan Anak Usia Dini (PAUD) di Provinsi Jambi”.

\section{METODE \\ Variabel dan Desain Penelitian}

Variabel dalam penelitian ini terdiri atas dua variabel yaitu media sebagai variabel bebas (variabel $\mathrm{X}$ ) dan guru PAUD sebagai variabel terikat (variabel Y) . Sedangkan desain penelitian bersifat deskriptif dengan pendekatan kuantitatif yang bertujuan memberikan gambaran secara sistematis tentang keadaan yang sedang berlangsung pada objek penelitian yaitu tentang peran media pembelajaran guru PAUD di provinsi Jambi. Menurut Arikunto (1998) apabila peneliti bermaksud mengetahui keadaan sesuatu mengenai apa dan bagaimana, berapa banyak dan sejauh mana, maka penelitiannya bersifat deskriptif, yaitu menjelaskan atau menerangkan peristiwa.

\section{Tempat dan Waktu Penelitian}

Lokasi penelitian ini yaitu dilaksanakan di PAUD di Provinsi Jambi. Alasan pemilihan lokasi ini untuk mengetahui peran media pembelajaran bagi guru PAUD di provinsi Jambi. Selanjutnya, waktu penelitian dimulai dari persiapan dan memperoleh hasil penelitian direncanakan akan berlangsung selama 8 bulan terhitung bulan Maret 2019 sampai bulan November 2019.

\section{Populasi dan Sampel}

Teknik yang digunakan dalam pengambilan sampel untuk mengetahui Peran media pembelajaran guru PAUD di Provinsi Jambi ini menggunakan teknik cluster sampling. Suatu metode dimana tidak tersedia kerangka sampel, masing-masing unit dari populasi disusun kedalam grup/cluster, dalam hal ini adalah Kabupaten dan Kota di Provinsi Jambi sebagai klusternya. Menurut data dari Kemendikbud (2018) di Provinsi Jambi terdapat 7.584 Pendidik satuan pendidikan (sekolah) anak usia dini diantaranya TK/RA, KB, TPA, dan SPS Kemudian setiap Kabupaten dan Kota dipilih sebanyak $10 \%$ secara random guru PAUD dari masing-masing sekolah. Jumlah sampelnya adalah 758. Unit sampel adalah Guru PAUD di Provinsi Jambi.

\section{Instrumen Penelitian}

Parameter penelitian ini adalah: Angket untuk mengetahui informasi guru PAUD (Lampiran I) dan Kuesioner Media Perception Evaluation Scale (MPES) yang berisikan 27 item pertanyaan. Sebanyak 758 guru PAUD di Provinsi Jambi dalam penelitian ini sebagai responden untuk mengisi instrument penelitian berupa angket atau kuesioner penelitian.Selanjutnya, Para responden diberikan instruksi untuk mengisi kuesioner yang telah di modifikasi yang berisi 28 pertanyaan dan 
item-item ini dicocokkan dengan skala tipe Likert yang memiliki lima kategori respons mulai dari sangat setuju hingga sangat tidak setuju (Lampiran II). Pertanyaan berisikan komponen positif dan negatif sehingga skor menjadi 100 .

\section{Teknik Analisis Data}

Setelah data terkumpul, selanjutnya data untuk semua parameter menggunakan database Microsoft Excel.Chi Sequaredigunakan untukmengukur apakah terdapat hubungan yang signifikan antara pendapat guru yang memiliki pengalaman belum sampai 2 tahun mengajar dan lebih dari 10 tahun mengajar terhadap penggunaan media belajar. Selain itu analisis ini digunakan untuk mengetahui Jenis media pembelajaran apa yang paling efektif bagi Guru PAUD di Provinsi Jambi. Semua analisis statistik dilakukan pada tingkat signifikansi 5\% dan $\mathrm{P}<0,05$ dianggap signifikan secara statistik.

\section{HASIL DAN PEMBAHASAN}

Penelitian tentang peran media pembelajaran guru PAUD di Provinsi Jambi telah dilakukan selama \pm 8 bulan di 9 Kabupaten (Batanghari, Bungo, Kerinci, Merangin, Muaro Jambi, Sarolangun, Tanjung Jabung Barat, Tanjung Jabung Timur, dan Tebo) dan 2 Kota (Jambi dan Sungaipenuh) di Provinsi Jambi. Pada penelitian ini dilakukan dengan menggunakan teknik cluster sampling untuk menentukan jumlah sampel sebagai responden. Hal ini dikarenakan tidak tersedia kerangka sampel dari masing-masing unit populasi yang disusun ke dalam grup/ cluster. Sehingga sampel yang didapatkan sebanyak 758 sampel dari unit sampel yaitu Guru PAUD di Provinsi Jambi.

Instrumen pada penelitian ini yaitu peneliti sebagai instrumen dan pengumpul data, sedangkan alat yang digunakan adalah kuesioner dan kamera. Sedangkan teknik pengumpulan data menggunakan data primer yang diperoleh dari guru PAUD di Provinsi Jambi. Wawancara dilakukan dengan menggunakan kuesioner dalam bentuk pertanyaan tertutup dan semi terbuka. Responden adalah guru PAUD pada saat survei dilaksanakan pada saat waktu pembelajaran telah selesai.

Sedangkan teknik analisis data menggunakan analisis deskriptif untuk mengidentifikasi responden. Selanjutnya data tersebut digunakan untuk mengetahui apakah terdapat hubungan yang signifikan antara pendapat guru yang memiliki pengalaman belum sampai 2 tahun mengajar dan lebih dari 10 tahun mengajar terhadap penggunaan media belajar. Selain itu analisis ini digunakan untuk mengetahui Jenis media pembelajaran apa yang paling efektif bagi Guru PAUD di Provinsi Jambi.

\section{Analisis Deskriptif Responden}

Melalui deskriptif analisis, penulis mencoba memberikan informasi secara general tentang informasi
Guru PAUD di provinsi Jambi dan penyebarankuisoner media perception evalution scale (MPES). Dari hasil kuesioner tersebut Guru PAUD di Provinsi Jambi menyatakan Bahwa media Pembelajaran sangat berperan dalam proses pembelajaran untuk anak-anak PAUD di Provinsi Jambi. Hasilnya sebanyak 59,6\% menjawab sangat setuju.

\section{Hubungan antara Guru yang Mengajar Kurang dari 2 Tahun dan yang Lebih dari 10 Tahun Terhadap Media Pembelajaran}

Pada bagian ini menjawab rumusan masalah yang pertama "Apakah ada hubungan antara guru yang mengajar kurang dari 2 tahun dan yang lebih dari 10 tahun masa mengajar terhadap media pembelajaran. Setelah menganalisis hasil dari perhitungan angket informasi Guru PAUD di Provinsi Jambi dengan mengkorelasikan hasilnya terhadap hasil kuisioner media perception evalution scale (MPES). Di sini peneliti mengkorelasikan kuisioner pada pertanyaan yang dimulai dari nomor 17-28 sebagai variabel $\mathrm{x}$ dan pertanyaan nomor 1 pada angket sebagai variabel $\mathrm{y}$. Pada perhitungan hasil pengkorelasian dua variabel ini menggunakan metode Chi Square yang terdapat pada SPSS22, berikut hasil nya:

Dari Pertanyaan 17 (MPES) hasil Pearson Chi Square 0,124, dapat dilihat dari nilai Asym.Sig.(2-sided) Ini dapat di artikan $0,124>0,05$ yang mana Null Hipotesis $\left(\mathrm{H}_{0}\right)$ diterima atau Alternatif Hipotesis $\left(\mathrm{H}_{\mathrm{a}}\right)$ di tolak. Dimana dapat dilihat bahwa $50,4 \%$ yang menyatakan bahwa media audio dapat memberikan motivasi dan merangsang anak untuk bereksplorasi dan berekseperimen.

\begin{tabular}{|l|r|r|r|r|r|r|}
\hline \multicolumn{1}{|c|}{ Case Processing Summary } \\
\cline { 2 - 8 } & \multicolumn{2}{|c|}{ Valid } & \multicolumn{2}{c|}{ Missing } & \multicolumn{2}{c|}{ Total } \\
\cline { 2 - 7 } & $\mathrm{N}$ & Percent & \multicolumn{1}{c|}{$\mathrm{N}$} & Percent & $\mathrm{N}$ & Percent \\
\hline $\begin{array}{l}\text { MEDIA_AUDIO_P17* } \\
\text { IENAG_PENDIDIK }\end{array}$ & 758 & $50.4 \%$ & 745 & $49.6 \%$ & 1503 & $100.0 \%$ \\
\hline
\end{tabular}

\begin{tabular}{|c|c|c|c|c|c|}
\hline \multicolumn{6}{|c|}{ MEDIA_AUDIO_P17* TENAGA_PENDIDIK Crosstabulation } \\
\hline \multicolumn{6}{|c|}{ 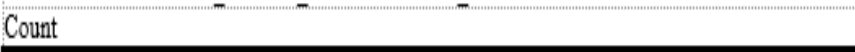 } \\
\hline & & \multicolumn{3}{|c|}{ TENAGA PENDIDIK } & \multirow[b]{2}{*}{ Total } \\
\hline & & 2 Tahun & $>10$ Tahun & 3.6 Tahun & \\
\hline \multirow[t]{5}{*}{ MEDIA_AUDIO_P17 } & Sangat Tidak Setuju & 14 & 14 & 10 & 38 \\
\hline & Tidak Setuju & 38 & 99 & 39 & 176 \\
\hline & Tidak Pasti & 40 & 122 & 48 & 210 \\
\hline & Setuju & 45 & 94 & 52 & 191 \\
\hline & Sangat Tidak Setuju & 38 & 65 & 40 & 143 \\
\hline Total & & 175 & 394 & 189 & 758 \\
\hline
\end{tabular}




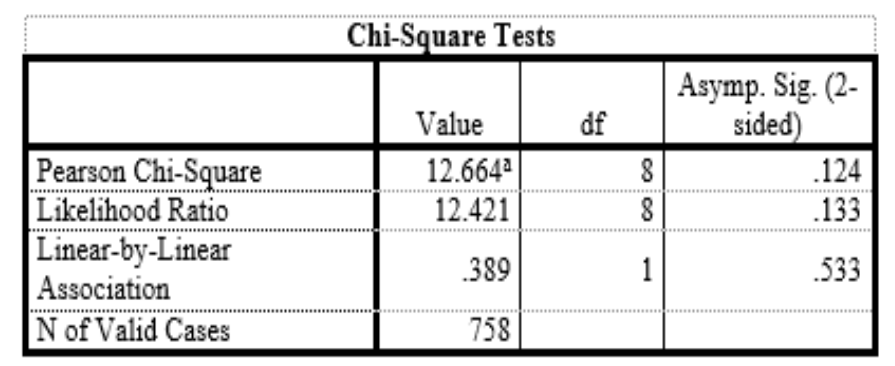

Pada pertanyaan 18 (MPES) hasil Pearson Chi Square 0,054, dapat dilihat dari nilai Asym.Sig.(2-sided) Ini dapat di artikan 0,054>0,05 yang mana Null Hipotesis $\left(\mathrm{H}_{0}\right)$ diterima atau Alternatif Hipotesis $\left(\mathrm{H}_{\mathrm{a}}\right)$ di tolak. Dimana dapat dilihat bahwa $100 \%$ yang menyatakan bahwa media visual dapat memberikan motivasi dan merangsang anak untuk bereksplorasi dan bereksperimen.

\begin{tabular}{|l|r|r|r|r|r|r|}
\hline & \multicolumn{7}{|c|}{ Cases } \\
\cline { 2 - 7 } & \multicolumn{2}{|c|}{ Valid } & \multicolumn{2}{c|}{ Missing } & \multicolumn{2}{c|}{ Total } \\
\cline { 2 - 7 } & $\mathrm{N}$ & Percent & $\mathrm{N}$ & Percent & \multicolumn{1}{c|}{$\mathrm{N}$} & Percent \\
\hline MEDIA_VISUAL_P18* & 758 & $100.0 \%$ & & $0.0 \%$ & 758 & $100.0 \%$ \\
\hline TENAGA_PENDIDIK & & & & & \\
\hline
\end{tabular}

\begin{tabular}{|c|c|c|c|c|}
\hline \multicolumn{5}{|c|}{ MEDIA_VISUAL_P18 * TENAGA_PENDIDIK Crosstabulation } \\
\hline 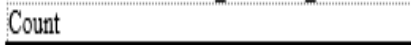 & & & & \\
\hline & \multicolumn{3}{|c|}{ TENAGA PENDIDIK } & \multirow[b]{2}{*}{ Total } \\
\hline & \&Tahun & >10 Tahun & 3.6 Tahun & \\
\hline MEDIA_VISUAL_P18 Sangat Tidak Setuju & 4 & 27 & 5 & 36 \\
\hline Tidak Setuju & 31 & 64 & 27 & 122 \\
\hline Tidak Pasti & 49 & 131 & 52 & 232 \\
\hline Setuju & 59 & 102 & 65 & 226 \\
\hline Sangat Tidak Setuju & 32 & 70 & 40 & 142 \\
\hline Total & 175 & 394 & 189 & 758 \\
\hline
\end{tabular}

\begin{tabular}{|l|r|r|r|}
\hline & Chi-Square Tests \\
& \multicolumn{1}{|c|}{ Value } & \multicolumn{1}{c|}{ df } & $\begin{array}{c}\text { Asymp. Sig. (2- } \\
\text { sided) }\end{array}$ \\
\hline Pearson Chi-Square & $15.290^{\mathrm{a}}$ & 8 & .054 \\
\hline Likelihood Ratio & 15.708 & 8 & .047 \\
\hline Linear-by-Linear & .740 & 1 & .390 \\
Association & 758 & & \\
\hline N of Valid Cases & & & \\
\hline
\end{tabular}

Pada pertanyaan 19 (MPES) hasil analisis Pearson Chi Square 0,001, dapat dilihat dari nilai Asym.Sig.(2sided) Ini dapat di artikan $0,001<0,05$ yang mana Null Hipotesis $\left(\mathrm{H}_{0}\right)$ ditolak atau alternatif Hipotesis $\left(\mathrm{H}_{\mathrm{a}}\right)$ diterima. Dimana dapat dilihat bahwa $100 \%$ yang menyatakan bahwa media audio-visual dapat memberikan motivasi dan merangsang anak untuk bereksplorasi dan bereksperimen.

\begin{tabular}{|c|c|c|c|c|c|c|}
\hline \multicolumn{7}{|c|}{ Case Processing Summary } \\
\hline & \multicolumn{6}{|c|}{ Cases } \\
\hline & \multicolumn{2}{|c|}{ Valid } & \multicolumn{2}{|c|}{ Missing } & \multicolumn{2}{|c|}{ Total } \\
\hline & $\mathrm{N}$ & Percent & $\begin{array}{ll}\mathrm{N} \\
\end{array}$ & Percent & $\mathrm{N}$ & Percent \\
\hline $\begin{array}{l}\text { MEDIA VISUAL_P19* } \\
\text { TENAGA_PENDIDIK }\end{array}$ & 758 & $100.0 \%$ & 0 & $0.0 \%$ & 758 & $100.0 \%$ \\
\hline
\end{tabular}

\begin{tabular}{|c|c|c|c|c|}
\hline \multicolumn{5}{|c|}{ MEDIA_VISUAL_P19 * TENAGA_PENDIDIK Crosstabulation } \\
\hline \multicolumn{5}{|l|}{ Count } \\
\hline & \multicolumn{3}{|c|}{ TENAGA_PENDIDIK } & \multirow[b]{2}{*}{ Total } \\
\hline & $<$ Tahun & $>10$ Tahun & 3.6 Tahun & \\
\hline MEDIA_VISUAL_P19 Sangat Tidak Setuju & 10 & 14 & 0 & 24 \\
\hline Tidak Setuju & 26 & 41 & 17 & 84 \\
\hline Tidak Pasti & 39 & 98 & 31 & 168 \\
\hline Setuju & 56 & 161 & 81 & 298 \\
\hline Sangat Tidak Setuju & 44 & 80 & 60 & 184 \\
\hline Total & 175 & 394 & 189 & 758 \\
\hline
\end{tabular}

\begin{tabular}{|l|r|r|r|}
\hline Chi-Square Tests & \multicolumn{1}{|c|}{ Value } & df & Asymp. Sig. (2-sided) \\
\hline Pearson Chi-Square & $27.236^{2}$ & 8 & .001 \\
\hline Likelihood Ratio & 32.490 & 8 & .000 \\
\hline Linear-by-Linear Association & 14.400 & 1 & .000 \\
\hline Nof Valid Cases & 758 & & \\
\hline
\end{tabular}

Pada Hasil pertanyaan nomor 20: Pearson Chi Square 0,551, dapat dilihat dari nilai Asym.Sig.(2-sided) Ini dapat diartikan 0,551>0,05 yang mana Null Hipotesis $\left(\mathrm{H}_{0}\right)$ diterima atau alternatif Hipotesis $\left(\mathrm{H}_{\mathrm{a}}\right)$ diterima. Ternyata media audio hanya dapat memberikan sedikit kontribusi terhadap respon umpan balik untuk anak-anak usia dini.

\begin{tabular}{|c|c|c|c|c|c|c|}
\hline \multicolumn{7}{|c|}{ Case Processing Summary } \\
\hline & \multicolumn{6}{|c|}{ Cases } \\
\hline & \multicolumn{2}{|c|}{ Valid } & \multicolumn{2}{|c|}{ Missing } & \multicolumn{2}{|c|}{ Total } \\
\hline & $\mathrm{N}$ & Percent & $\mathrm{N}$ & Percent & $\mathrm{N}$ & Percent \\
\hline $\begin{array}{l}\text { MEDIA_AUDIO_P20* } \\
\text { TENAGA_PENDIDIK }\end{array}$ & 758 & $100.0 \%$ & 0 & $0.0 \%$ & 758 & $100.0 \%$ \\
\hline
\end{tabular}

\begin{tabular}{|c|c|c|c|c|c|}
\hline \multicolumn{6}{|c|}{ MEDIA_AUDIO P20 * TENAGA PENDIDIK Crosstabulation } \\
\hline \multicolumn{6}{|c|}{ 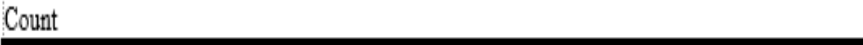 } \\
\hline & & \multicolumn{3}{|c|}{ TENAGA PENDIDIK } & \multirow[b]{2}{*}{ Total } \\
\hline & & $\angle$ Tahun & $>10$ Tahun & 3.6 Tahun & \\
\hline \multirow[t]{5}{*}{ MEDIA_AUDIO_P20 } & Sangat Tidak Setuju & 5 & 17 & 7 & 29 \\
\hline & Tidak Setuju & 34 & 85 & 31 & 150 \\
\hline & Tidak Pasti & 59 & 136 & 69 & 264 \\
\hline & Setuju & 40 & 89 & 54 & 183 \\
\hline & Sangat Tidak Setuju & 37) & 67 & 28 & 132 \\
\hline Total & & 175 & 394 & 189 & 758 \\
\hline
\end{tabular}




\begin{tabular}{|l|r|r|r|}
\hline & \multicolumn{4}{|c|}{ Chi-Square Tests } \\
\hline & \multicolumn{1}{|c|}{ Value } & df & $\begin{array}{c}\text { Asymp. Sig. (2- } \\
\text { sided) }\end{array}$ \\
\hline Pearson Chi-Square & $6.868^{\mathrm{a}}$ & 8 & .551 \\
\hline Likelihood Ratio & 6.823 & 8 & .556 \\
\hline Linear-by-Linear & .205 & 1 & .651 \\
Association & 758 & & \\
\hline N of Valid Cases & & & \\
\hline
\end{tabular}

Pada pertanyaan nomor 21: Pearson Chi Square 0,059, dapat dilihat dari nilai Asym. Sig.(2-sided) Ini dapat diartikan $0,059<0,05$ yang mana Null Hipotesis $\left(\mathrm{H}_{0}\right)$ diterima atau alternatif Hipotesis $\left(\mathrm{H}_{\mathrm{a}}\right)$ di tolak. Media video dapat memberikan respon berupa umpan balik kepada anak-anak usia dini.

\begin{tabular}{|c|c|c|c|c|c|c|}
\hline \multicolumn{7}{|c|}{ Case Processing Summary } \\
\hline & \multicolumn{6}{|c|}{ Cases } \\
\hline & \multicolumn{2}{|c|}{ Valid } & \multicolumn{2}{|c|}{ Missing } & \multicolumn{2}{|c|}{ Total } \\
\hline & $\mathrm{N}$ & Percent & $\mathrm{N}$ & Percent & $\mathrm{N}$ & Percent \\
\hline $\begin{array}{l}\text { MEDIA_VISUAL_P21 * } \\
\text { TENAGA_PENDIDIK }\end{array}$ & 758 & $100.0 \%$ & 0 & $0.0 \%$ & 758 & $100.0 \%$ \\
\hline
\end{tabular}

\begin{tabular}{|c|c|c|c|c|}
\hline \multicolumn{5}{|c|}{ MEDIA_VISUAL_P21 * TENAGA_PENDIDIK Crosstabulation } \\
\hline \multicolumn{5}{|l|}{ Count } \\
\hline & & AGA_PENDII & & \\
\hline & $\angle$ Tahun & >10 Tahun & 3.6 Tahun & Total \\
\hline MEDIA_VISUAL_P21 Sangat Tidak Setuju & 3 & 7 & 2 & 12 \\
\hline Tidak Setuju & 34 & 57 & 18 & 109 \\
\hline Tidak Pasti & 52 & 163 & 69 & 284 \\
\hline Setuju & 51 & 104 & 58 & 213 \\
\hline Sangat Tidalk Settju & 35 & 63 & 42 & 140 \\
\hline Total & 175 & 394 & 189 & 758 \\
\hline
\end{tabular}

\begin{tabular}{|l|r|r|r|}
\hline & Chi-Square Tests \\
& \multicolumn{1}{|c|}{ Value } & \multicolumn{1}{c|}{ df } & $\begin{array}{c}\text { Asymp. Sig. (2- } \\
\text { sided) }\end{array}$ \\
\hline Pearson Chi-Square & $15.001^{\mathrm{a}}$ & 8 & .059 \\
\hline Likelihood Ratio & 15.281 & 8 & .054 \\
\hline $\begin{array}{l}\text { Linear-by-Linear } \\
\text { Association }\end{array}$ & 2.870 & 1 & .090 \\
\hline N of Valid Cases & 758 & & \\
\hline
\end{tabular}

Pertanyaan 22 (MPES) hasil Pearson Chi Square 0,058, dapat dilihat dari nilai Asym.Sig.(2-sided) Ini dapat diartikan $0,058<0,05$ yang mana Null Hipotesis $\left(\mathrm{H}_{0}\right)$ diterima atau alternatif Hipotesis $\left(\mathrm{H}_{\mathrm{a}}\right)$ ditolak. Sehingga hasil yang didapatkan bahwa media AudioVisual ini dapat memberikan respon umpan balik untuk proses pembelajaran anak usia dini.

\begin{tabular}{|c|c|c|c|c|c|c|}
\hline \multicolumn{7}{|c|}{ Case Processing Summary } \\
\hline & \multicolumn{6}{|c|}{ Cases } \\
\hline & \multicolumn{2}{|c|}{ Valid } & \multicolumn{2}{|c|}{ Missing } & \multicolumn{2}{|c|}{ Total } \\
\hline & $\mathrm{N}$ & Percent & $\mathrm{N}$ & Percent & $\mathrm{N}$ & Percent \\
\hline $\begin{array}{l}\text { MEDIA_AUDIOVISUAL_ } \\
\text { P22* } \\
\text { TENAGA_PENDIDIK }\end{array}$ & 758 & $100.0 \%$ & 0 & $0.0 \%$ & 758 & $100.0 \%$ \\
\hline
\end{tabular}

\section{MEDIA AUDIOVISUAL P22 * TENAGA PENDIDIK Crosstabulation}

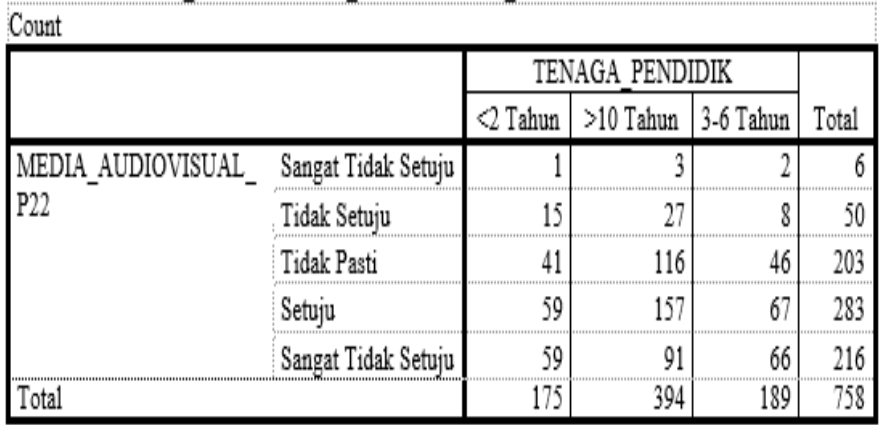

\begin{tabular}{|l|r|r|r|}
\hline \multicolumn{4}{|c|}{ Chi-Square Tests } \\
\hline & \multicolumn{1}{|c|}{ Value } & df & $\begin{array}{c}\text { Asymp. Sig. (2- } \\
\text { sided) }\end{array}$ \\
\hline Pearson Chi-Square & $15.055^{\mathrm{a}}$ & 8 & .058 \\
\hline Likelihood Ratio & 15.220 & 8 & .055 \\
\hline $\begin{array}{l}\text { Linear-by-Linear } \\
\text { Association }\end{array}$ & .705 & 1 & .401 \\
\hline N of Valid Cases & 758 & & \\
\hline
\end{tabular}

Pada hasil pertanyaan nomor 23: Pearson Chi Square 0,055, dapat dilihat dari nilai Asym.Sig.(2-sided) Ini dapat diartikan 0,055>0,05 yang mana Null Hipotesis $\left(\mathrm{H}_{0}\right)$ diterima atau alternatif Hipotesis $\left(\mathrm{H}_{\mathrm{a}}\right)$ di tolak. Dimana dengan proses pembelajaran menggunakan media audio 99,6\% dapat membantu guru PAUD dalam menilai/mengevaluasi 6 aspek perkembangan anak-anak; agama, moral, fisik-motorik, kognitif, bahasa, sosialemosional, dan seni.

\begin{tabular}{|c|c|c|c|c|c|c|}
\hline \multicolumn{7}{|c|}{ Case Processing Summary } \\
\hline & \multicolumn{6}{|c|}{ Cases } \\
\hline & \multicolumn{2}{|c|}{ Valid } & \multicolumn{2}{|c|}{ Missing } & \multicolumn{2}{|c|}{ Total } \\
\hline & $\mathrm{N}$ & Percent & $\mathrm{N}$ & Percent & $\mathrm{N}$ & Percent \\
\hline $\begin{array}{l}\text { MEDIA_AUDIO_P23* } \\
\text { TENAGA_PENDIDIK }\end{array}$ & 755 & $99.2 \%$ & 6 & $0.8 \%$ & 761 & $100.0 \%$ \\
\hline
\end{tabular}




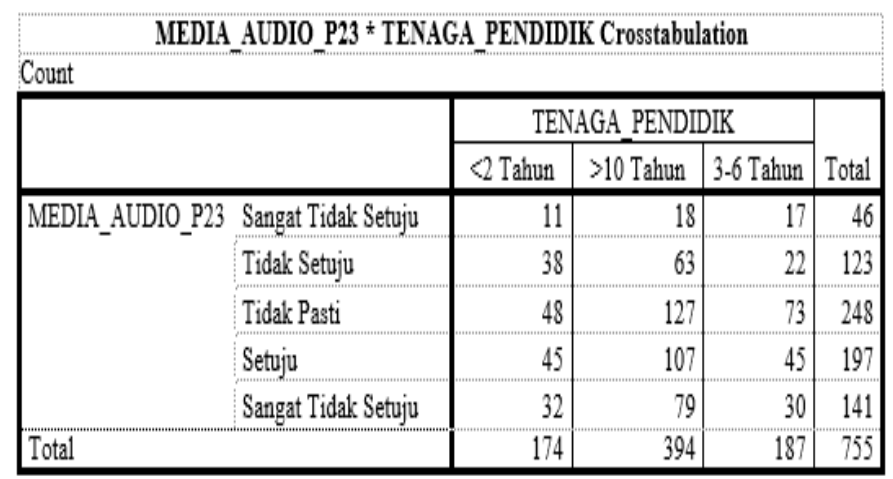

\begin{tabular}{|l|r|r|r|}
\hline \multicolumn{4}{|c|}{ Chi-Square Tests } \\
\hline & \multicolumn{1}{|c|}{ Value } & df & $\begin{array}{c}\text { Asymp. Sig. (2- } \\
\text { sided) }\end{array}$ \\
\hline Pearson Chi-Square & $15.200^{\mathrm{d}}$ & 8 & .055 \\
\hline Likelihood Ratio & 14.904 & 8 & .061 \\
\hline Linear-by-Linear & .044 & 1 & .833 \\
Association & 755 & & \\
\hline N of Valid Cases & & & \\
\hline
\end{tabular}

Hasil pertanyaan 24 (MPES) Pearson Chi Square 0,100, dapat dilihat dari nilai Asym.Sig.(2-sided) Ini dapat diartikan 0,100>0,05 yang mana Null Hipotesis $\left(\mathrm{H}_{0}\right)$ diterima atau alternatif Hipotesis $\left(\mathrm{H}_{\mathrm{a}}\right)$ di tolak. Pada pertanyaan 25 (MPES) hasil Pearson Chi Square 0,006, dapat dilihat dari nilai Asym.Sig.(2-sided) Ini dapat diartikan $0,006<0,05$ yang mana Null Hipotesis $\left(\mathrm{H}_{0}\right)$ ditolak atau alternatif Hipotesis $\left(\mathrm{H}_{\mathrm{a}}\right)$ diterima. Dimana dengan proses pembelajaran menggunakan media video 99,6\% dapat membantu guru PAUD dalam menilai/mengevaluasi 6 aspek perkembangan anak-anak; agama, moral, fisik-motorik, kognitif, bahasa, sosialemosional, dan seni.

\begin{tabular}{|c|c|c|c|c|c|c|}
\hline \multicolumn{7}{|c|}{ Case Processing Summary } \\
\hline & \multicolumn{6}{|c|}{ Cases } \\
\hline & \multicolumn{2}{|c|}{ Valid } & \multicolumn{2}{|c|}{ Missing } & \multicolumn{2}{|c|}{ Total } \\
\hline & $\mathrm{N}$ & Percent & $\mathrm{N}$ & Percent & $\mathrm{N}$ & Percent \\
\hline $\begin{array}{l}\text { MEDIA_VISUAL_P24* } \\
\text { TENAGA_PENDIDIK }\end{array}$ & 758 & $99.6 \%$ & 3 & $0.4 \%$ & 761 & $100.0 \%$ \\
\hline
\end{tabular}

\begin{tabular}{|c|c|c|c|c|}
\hline \multicolumn{5}{|c|}{ MEDIA_VISUAL_P24 * TENAGA_PENDIDIK Crosstabulation } \\
\hline \multicolumn{5}{|l|}{ Count } \\
\hline & & AGA PENDI & & \\
\hline & $<$ Tahun & >10 Tahun & 3.6 Tahun & Total \\
\hline MEDIA_VISUAL_P24 Sangat Tidak Setuju & 10 & 14 & 17 & 41 \\
\hline Tidak Setuju & 31 & 50 & 21 & 102 \\
\hline Tidak Pasti & 50 & 135 & 69 & 254 \\
\hline Setuju & 52 & 125 & 53 & 230 \\
\hline Sangat Tidak Setuju & 32 & 70 & 29 & 131 \\
\hline Total & 175 & 394 & 189 & 758 \\
\hline
\end{tabular}

\begin{tabular}{|l|r|r|r|}
\hline \multicolumn{4}{|c|}{ Chi-Square Tests } \\
\hline & \multicolumn{1}{|c|}{ Value } & \multicolumn{1}{c|}{ df } & $\begin{array}{c}\text { Asymp. Sig. (2- } \\
\text { sided) }\end{array}$ \\
\hline Pearson Chi-Square & $13.348^{\mathrm{a}}$ & 8 & .100 \\
\hline Likelihood Ratio & 12.850 & 8 & .117 \\
\hline Linear-by-Linear & .502 & 1 & .479 \\
Association & 758 & & \\
\hline Nof Valid Cases & & & \\
\hline
\end{tabular}

Pada pertanyaan 25 (MPES) hasil Pearson Chi Square 0,006, dapat dilihat dari nilai Asym.Sig.(2-sided) Ini dapat diartikan 0,006<0,05 yang mana Null Hipotesis $\left(\mathrm{H}_{0}\right)$ ditolak atau Alternatif Hipotesis $\left(\mathrm{H}_{\mathrm{a}}\right)$ diterima. Dimana dengan proses pembelajaran menggunakan media Audio- visual 99,6\% dapat membantu guru PAUD dalam menilai/mengevaluasi 6 aspek perkembangan anak-anak; agama, moral, fisik-motorik, kognitif, bahasa, sosial-emosional, dan seni.

\begin{tabular}{|c|c|c|c|c|c|c|}
\hline \multicolumn{7}{|c|}{ Case Processing Summary } \\
\hline & \multicolumn{6}{|c|}{ Cases } \\
\hline & \multicolumn{2}{|c|}{ Valid } & \multicolumn{2}{|c|}{ Missing } & \multicolumn{2}{|c|}{ Total } \\
\hline & $\mathrm{N}$ & Percent & $\mathrm{N}$ & Percent & $\mathrm{N}$ & Percent \\
\hline $\begin{array}{l}\text { MEDIA_AUDIOVISUAL_ } \\
\text { P25* } \\
\text { TENAGA_PENDIDIK }\end{array}$ & 758 & $99.6 \%$ & 3 & $0.4 \%$ & 761 & $100.0 \%$ \\
\hline
\end{tabular}

\begin{tabular}{|c|c|c|c|c|c|}
\hline \multicolumn{6}{|c|}{ MEDIA_AUDIOVISUAL_P25 * TENAGA_PENDIDIK Crosstabulation } \\
\hline \multicolumn{6}{|l|}{ Count } \\
\hline & & \multicolumn{3}{|c|}{ TENAGA PENDIDIK } & \multirow[b]{2}{*}{ Total } \\
\hline & & \&Tahun & >10 Tahun & 3.6 Tahun & \\
\hline \multirow{5}{*}{$\begin{array}{l}\text { MEDIA_AUDIOVISUAL_ } \\
\text { P25 }\end{array}$} & Sangat Tidak Setuju & 1 & 8 & 1 & 10 \\
\hline & Tidak Setuju & 19 & 30 & 18 & 67 \\
\hline & Tidak Pasti & 60 & 94 & 60 & 214 \\
\hline & Setuju & 49 & 178 & 73 & 300 \\
\hline & Sangat Tidak Setuju & 46 & 84 & 37 & 167 \\
\hline \multicolumn{2}{|l|}{ Total } & 175 & 394 & 189 & 758 \\
\hline
\end{tabular}

Chi-Square Tests

\begin{tabular}{|l|r|r|r|}
\hline & \multicolumn{1}{|c|}{ Value } & df & $\begin{array}{c}\text { Asymp. Sig. (2- } \\
\text { sided) }\end{array}$ \\
\hline Pearson Chi-Square & $21.628^{\mathrm{a}}$ & 8 & .006 \\
\hline $\begin{array}{l}\text { Likelihood Ratio } \\
\text { Linear-by-Linear } \\
\text { Association }\end{array}$ & 22.306 & 8 & .004 \\
\hline N of Valid Cases & .029 & 1 & .864 \\
\hline
\end{tabular}

Pada pertanyaan 26 hasil Person Chi Square 0,629, dapat dilihat dari nilai Asym.Sig.(2-sided) Ini dapat diartikan 0,629>0,05 yang mana Null Hipotesis $\left(\mathrm{H}_{0}\right)$ diterima atau alternatif Hipotesis $\left(\mathrm{H}_{\mathrm{a}}\right)$ ditolak. Dalam proses pembelajaran PAUD ternyata media audio saja tidak akan efektif dan efisien. 


\begin{tabular}{|l|r|r|r|r|r|r|}
\hline & \multicolumn{7}{|c|}{ Case Processing Summary } \\
\cline { 2 - 8 } & \multicolumn{2}{|c|}{ Valid } & \multicolumn{2}{c|}{ Missing } & \multicolumn{2}{c|}{ Total } \\
\cline { 2 - 8 } & $\mathrm{N}$ & Percent & \multicolumn{1}{c|}{$\mathrm{N}$} & Percent & $\mathrm{N}$ & Percent \\
\hline $\begin{array}{l}\text { MEDIA_AUDI0_P26* } \\
\text { TENAGA_PENDIDIK }\end{array}$ & 758 & $99.6 \%$ & & $0.4 \%$ & 761 & $100.0 \%$ \\
\hline
\end{tabular}

\begin{tabular}{|c|c|c|c|c|c|}
\hline \multicolumn{6}{|c|}{ MEDIA_AUDI0 P26 * TENAGA_PENDIDIK Crosstabulation } \\
\hline \multicolumn{6}{|c|}{ 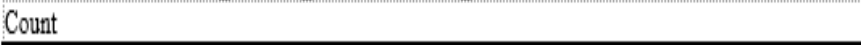 } \\
\hline & & \multicolumn{3}{|c|}{ TENAGA_PENDIDIK } & \multirow[b]{2}{*}{ Total } \\
\hline & & 2 Tahun & $>10$ Tahun & 3.6 Tahun & \\
\hline \multirow[t]{5}{*}{ MEDIA_AUDI0_P26 } & Sangat Tidak Setuju & 14 & 26 & 21 & 61 \\
\hline & Tidak Setuju & 36 & 69 & 35 & 140 \\
\hline & Tidak Pasti & 52 & 133 & 61 & 246 \\
\hline & Setuju & 42 & 89 & 44 & 175 \\
\hline & Sangat Tidak Setuju & 31 & 77 & 28 & 136 \\
\hline Total & & 175 & 394 & 189 & 758 \\
\hline
\end{tabular}

\begin{tabular}{|l|r|r|r|}
\multicolumn{4}{|c|}{ Chi-Square Tests } \\
\hline & Value & df & $\begin{array}{c}\text { Asymp. Sig. (2- } \\
\text { sided) }\end{array}$ \\
\hline Pearson Chi-Square & $6.165^{\mathrm{a}}$ & 8 & .629 \\
\hline Likelihood Ratio & 6.044 & 8 & .642 \\
\hline Linear-by-Linear & .820 & 1 & .365 \\
Association & 758 & & \\
\hline N of Valid Cases & & & \\
\hline
\end{tabular}

Pada pertanyaan 27 hasil yang didapatakandari Pearson Chi Square 0,926, dapat dilihat dari nilai Asym.Sig.(2-sided) Ini dapat diartikan 0,926>0,05 yang mana Null Hipotesis $\left(\mathrm{H}_{0}\right)$ diterima atau alternatif Hipotesis $\left(\mathrm{H}_{\mathrm{a}}\right)$ ditolak. Dalam proses pembelajaran PAUD ternyata media video saja tidak akan efektif dan efisien.

\begin{tabular}{|c|c|c|c|c|c|c|}
\hline \multicolumn{7}{|c|}{ Case Processing Summary } \\
\hline & \multicolumn{6}{|c|}{ Cases } \\
\hline & \multicolumn{2}{|c|}{ Valid } & \multicolumn{2}{|c|}{ Missing } & \multicolumn{2}{|c|}{ Total } \\
\hline & $\mathrm{N}$ & Percent & $\mathrm{N}$ & Percent & $\mathrm{N}$ & Percent \\
\hline $\begin{array}{l}\text { MEDIA_VISUAL_P27* } \\
\text { TENAGA_PENDIDIK }\end{array}$ & 758 & $99.6 \%$ & 3 & $0.4 \%$ & 761 & $100.0 \%$ \\
\hline
\end{tabular}

\begin{tabular}{|c|c|c|c|c|c|}
\hline \multicolumn{6}{|c|}{ MEDIA VISUAL_P27 * TENAGA_PENDIDIK Crosstabulation } \\
\hline \multicolumn{6}{|c|}{ 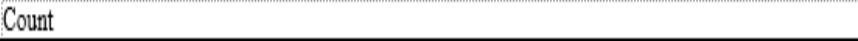 } \\
\hline & & \multicolumn{3}{|c|}{ TENAGA PENDIDIK } & \multirow[b]{2}{*}{ Total } \\
\hline & & 2 Tahun & >10 Tahun & 3.6 Tahun & \\
\hline \multirow[t]{5}{*}{ MEDIA_VISUAL_P27 } & Sangat Tidak Setuju & 4 & 11 & 7 & 22 \\
\hline & Tidak Setuju & 24 & 66 & 26 & 116 \\
\hline & Tidak Pasti & 71 & 142 & 68 & 281 \\
\hline & Settuju & 47 & 101 & 52 & 200 \\
\hline & Sangat Tidak Setuju & 29 & 74 & 36 & 139 \\
\hline Total & & 175 & 394 & 189 & 758 \\
\hline
\end{tabular}

\begin{tabular}{|l|r|r|r|}
\hline & Chi-Square Tests \\
\hline & Value & \multicolumn{1}{|c|}{ df } & $\begin{array}{c}\text { Asymp. Sig. (2- } \\
\text { sided) }\end{array}$ \\
\hline Pearson Chi-Square & $3.122^{\mathrm{a}}$ & 8 & .926 \\
\hline $\begin{array}{l}\text { Likelihood Ratio } \\
\text { Linear-by-Linear }\end{array}$ & 3.104 & 8 & .928 \\
Association & .066 & 1 & .797 \\
\hline N of Valid Cases & 758 & & \\
\hline
\end{tabular}

Pada Hasil pertanyaan nomor 28Pearson Chi Square 0,017, dapat dilihat dari nilai Asym. Sig. (2sided) Ini dapat diartikan $0,017<0,05$ yang mana Null Hipotesis $\left(\mathrm{H}_{0}\right)$ ditolak atau alternatif Hipotesis $\left(\mathrm{H}_{\mathrm{a}}\right)$ diterima. Dalam proses pembelajaran PAUD ternyata media audio-visual sangat efektif dan efisien.

\begin{tabular}{|l|r|r|r|r|r|r|}
\hline \multicolumn{7}{|c|}{ Case Processing Summary } \\
\cline { 2 - 7 } & \multicolumn{2}{|c|}{ Valid } & \multicolumn{2}{|c|}{ Missing } & \multicolumn{2}{c|}{ Total } \\
\cline { 2 - 7 } & $\mathrm{N}$ & Percent & \multicolumn{1}{c|}{$\mathrm{N}$} & \multicolumn{1}{c|}{ Percent } & \multicolumn{1}{c|}{ N } & Percent \\
\hline $\begin{array}{l}\text { MEDIA_AUDIOVISUAL_ } \\
\text { P28* }\end{array}$ & 758 & $99.6 \%$ & 3 & $0.4 \%$ & 761 & $100.0 \%$ \\
TENAGA_PENDIDIK & & & & & & \\
\hline
\end{tabular}

\begin{tabular}{|c|c|c|c|c|c|}
\hline \multicolumn{6}{|c|}{ MEDIA_AUDIOVISUAL_P28 * TENAGA_PENDIDIK Crosstabulation } \\
\hline \multicolumn{6}{|l|}{ Count } \\
\hline & & \multicolumn{3}{|c|}{ TENAGA PENDIDIK } & \multirow[b]{2}{*}{ Total } \\
\hline & & ¿2Tahun & $>10$ Tahun & 3.6 Tahun & \\
\hline \multirow{6}{*}{$\begin{array}{l}\text { MEDIA_AUDIOVISUAL_ } \\
\text { P28 }\end{array}$} & 0 & 0 & 1 & 0 & 1 \\
\hline & Sangat Tidak Setuju & 6 & 11 & 4 & 21 \\
\hline & Tidak Setuju & 22 & 33 & 4 & 59 \\
\hline & Tidak Pasti & 39 & 77 & 44 & 160 \\
\hline & Setuju & 58 & 145 & 87 & 290 \\
\hline & Sangat Tidak Setuju & 50 & 127 & 50 & 227 \\
\hline Total & & 175 & 394 & 189 & 758 \\
\hline
\end{tabular}

\begin{tabular}{|l|r|r|r|}
\hline & \multicolumn{4}{|c|}{ Chi-Square Tests } \\
\hline & \multicolumn{1}{|c|}{ Value } & \multicolumn{1}{c|}{ df } & $\begin{array}{c}\text { Asymp. Sig. (2- } \\
\text { sided) }\end{array}$ \\
\hline Pearson Chi-Square & $21.583^{\mathrm{a}}$ & 10 & .017 \\
\hline $\begin{array}{l}\text { Likelihood Ratio } \\
\text { Linear-by-Linear }\end{array}$ & 24.247 & 10 & .007 \\
Association & 3.946 & 1 & .047 \\
\hline Nof Valid Cases & 758 & & \\
\hline
\end{tabular}

\section{SIMPULAN}

Hasil penelitian tentang peran media pembelajaran guru pendidikan anak usia dini (PAUD) di Provinsi Jambi dapat disimpulkan sebagai berikut.

1. Hubungan antara Guru PAUD yang memiliki pengalaman mengajar lebih atau kurang dari 2 tahun terhadap peran media pembelajaran sangat berkolerasi hal dari hasil rtabel < rhitung sehingga pertanyaan tersebut valid dan realibitas. 
2. Pembelajaran menggunakan media untuk anak-anak usia dini sangat berperan dalam untuk memotivasi dan merangsang anak untuk bereksplorasi dan bereksperimen, dapat memberikan umpan balik, serta Guru dibantu oleh media dalam proses menila/mengevaluasi 6 aspek perkembangan anakanak.

3. Media Audi-Visual lebih efektif dan efisien dalam proses pembelajaran untuk anak usia dini.

\section{DAFTAR PUSTAKA}

Arikunto, S., 2011. Penelitian Tindakan Kelas. Jakarta: Bumi Aksara

Arsyad, A., 2001. Media Pembelajaran. Jakarta: PT. Raja Grafindo Persada

Asyhar, R., 2011. Kreatif MengembangkanMedia Pembelajaran. Gaung. Persada

Fadillah, M., 2012. Desain Pembelajaran PAUD. Yogyakarta: AR-RUZZ Media

Kemendikbud, 2018. Data Referensi Jumlah Data Satuan Pendidikan (Sekolah) Anak Usia Dini Per Kabupaten/Kota : Kota Jambi. Jakarta: Kementerian Pendidikan dan Kebudayaan. http://referensi.data.kemdikbud.go.id/. Diakses Pada Tanggal 15 November 2018.

Moeslichatoen, R. 1999. Metode Pengajaran di Taman Kanak-Kanak. Jakarta: PT. Rineka Cipta

Rahman, Hibana, S., 2005, Konsep Dasar Pendidikan Anak Usia Dini. Yogyakarta: PGTKI Press

Yamin, Martinis, dan Jamilah, S.S., 2012. Panduan PAUD. Jakarta: Gaung Persada Press Group

Yuliani, S.N., 2012. Konsep Dasar Pendidikan Anak Usia Dini. Jakarta: Permata Putri Media

Zaman, B., Hernawan, A.H., dan Eliyawati, C., 2009. Media dan Sumber Belajar Taman Kanak-Kanak. Jakarta: Universitas Terbuka 